\title{
血液透析中の慢性腎不全患者における下垂体一副腎皮質機能について
}

\author{
長谷川弘一 小田初夫 大伴清馬岡本輝夫* 森井浩世*
}

大阪市立城北市民病院内科 大阪市立大学医学部第 2 内科*

(昭和 56 年. 8 月 21 日受付)

Key words：下垂体一副腎皮質機能，ACTH, cortisol，血液透析，慢性腎不全患者

〈要旨〉

血液透析中の慢性腎不全患者の低血圧の成因の 1 つとし下垂体一副腎皮質機能について検討するために血中 ACTH, cortisol を測定したところ血中 ACTHレベルは正常範囲内にあり，血漿 cortisol レベルも正常範囲よりゃや高 值を示した。低血圧群, 正常血圧群, 高血圧群の 3 群の間にはACTH, cortisolレベルとも有意の差を認めなかった。 そして ACTH と cortisol レベルの間には有意の関係ではないが弱い負の関係をみた．血液透析前後の血中 cortisol レ ベルは全体として透析後は透析前に比して高值を示したが低血圧群では後值は前值に比して低下しており緩除な透析 が原因と考えられた。

血液透析前後の cortisol 比と透析による体重減少率及び血液透析前後の中間血圧の比については有意の関係をみ た。すなわち透析による水分除去量, 中間血圧の低下が大きいほど cortisol 值は上昇をみた。腹膜灌流中の慢性腎不全 患者の灌流中の経時的変化では ACTH, cortisol レベルは平行した関係を示した.ACTH, cortisolレベルの日内変動に ついては健常人と同一のパターンを示した。さらに rapid ACTHテストは正常反応を示した。以上の成績より血液透 析中の慢性腎不全患者の下垂体一副腎皮質機能は正常であり，血液透析前の低血圧の成因として下垂体一副腎皮質が 関与している可能性は少ないものと思われた。

\section{Pituitary adrenocortical function in dialysed patients with chronic renal failure}

\section{Koichi Hasegawa Motoo Oda Seima Otomo Teruo Okamoto* Hirotoshi Morii*}

Shirokita Municipal Hospital. Second Department of Internal Medicine, Osaka City University Medical School.*

Plasma levels of ACTH and cortisol were measured by radioimmunoassay in dialysed patients with chronic renal failure. Plasma ACTH levels were almost within the normal range and cortisol levels were slightly higher than the normal levels. Statistically significant difference in plasma ACTH and cortisol level was not found among the hypotensive, normotensive and hypertensive group in dialysed patients with chronic renal failure and there was no statistically significant correlation between the levels of plasma ACTH and cortisol. The mean levels of plasma cortisol before hemodialysis were higher than the levels after that and there was a significant difference between the ratio of plasma cortisol level before and after hemodialysis (Fa/Fb) and weight loss following hemodialysis and between $\mathrm{Fa} / \mathrm{Fb}$ and of mean blood pressure. Diurnal rhythm of plasma ACTH and cortisol levels in dialysed patients with chronic renal failure were similar to the levels in healthy subjects. Rapid ACTH test showed normal response in the patients.

These findings may indicate that pituitary adrenocortical function was almost normal and that there would be no possibility that the pituitary adrenocortical system plays a role as a hypotensive factor in dialysed patients with chronic renal failure.

\section{緒言}

血液透析中の慢性腎不全患者の中には血液透析により 高度の全身倦怠感及び低血圧によりショック状態を生じ るものがあり透析の継続に大きな障害となっている。そ
こで血液透析中の慢性腎不全患者の低血圧に注目した。 血液透析患者の低血圧の原因として中枢及び自律神経系 の失調，血管壁昇圧反応の低下，本態性低血圧，心機能 低下, 内分泌障害，心因等が考えられる。内分泌障害に 
よるものとしてはレニン・アンギオテンシン・アルドス テロン系の障害, 副腎機能低下, 甲状腺機能低下などが ある。

最近の radioimmunoassay の進歩は種々なホルモン の測定を可能とし, 血液透析中の慢性腎不全患者におい ても各種ホルモンの測定值が報告されている，血液透析 中の慢性腎不全患者においては下垂体一副腎皮質系はほ ほ正常であるといわれているが詳細な報告は比較的少な い。とくに低血圧症例に打ける下垂体一副腎皮質機能の 解明が血液透析時のショックの予防に大きなカギとなっ ている.

\section{目的}

血液透析中の慢性腎不全患者の低血圧の成因の 1 つ して下垂体一副腎皮質系について検討するために血中 $\mathrm{ACTH}$, cortisol 測定し, 一部分の症例に rapid $\mathrm{ACTH}$ テストを実施した.

\section{対象及び方法}

ステロイドの投与をうけていない $18 〜 52$ 歳までの血 液透析中の慢性腎不全患者 36 例（男 21 例，女 15 例）を 対象とした。その透析期間は 12〜49 か月であった。全例 血液透析開始直前の午前 9 時に採血を行った。またうち 4 例については血液透析中経時的に採血を行った。ささら に血液透析患者の日内変動をみるために血液透析中の慢 性腎不全患者 4 例, 健常人 4 例について血液透析非施行 日の午前 7 時, 午後 4 時, 午後 11 時に採血を行った.

ACTH は CIS 製の抽出操作を必要としない radioimmunoassay kitを使用した。また cortisol は栄研の kit を使用した。ACTHの測定にあたりへパリン添加によっ て非特異的に高值を示すことが報告されているために1 血液透析中経時的に採血した検体については cortisolの み測定した。

\section{結果}

1）血液透析中の慢性腎不全患者の血中 ACTH, cortisol 基礎值（図 1).

対象とした 36 例について採血前 1 か月の透析開始時 の血圧より中間血圧が $110 \mathrm{mmHg}$ 以上を高血圧群, 収縮 期血圧が $100 \mathrm{mmHg}$ 以下を低血圧群, その間の血圧を正 常血圧群としてこれら 36 例を分類したところ高血圧群 17 例, 正常血圧群 11 例, 低血圧群 8 例であった。これら 3 群の ACTH， cortisol レベルを図1に示した。

ACTHについては高血圧群は $59.3 \pm 33.8 \mathrm{pg} / \mathrm{m} l$ (Mean \pm S.D.), 正常血圧群は $36.8 \pm 15.8 \mathrm{pg} / \mathrm{m} l$, 低血圧 群は $39.3 \pm 24.1 \mathrm{pg} / \mathrm{ml}$ でありおのおのの群の間には有 意の差を認めなかった. cortisolについては高血圧群は $10.8 \pm 3.5 \mu \mathrm{g} / \mathrm{d} l$, 正常血圧群は $12.1 \pm 2.3 \mu \mathrm{g} / \mathrm{d} l$, 低血圧 群は $14.0 \pm 3.1 \mu \mathrm{g} / \mathrm{d} l$ でありおのおのの群の間には有意

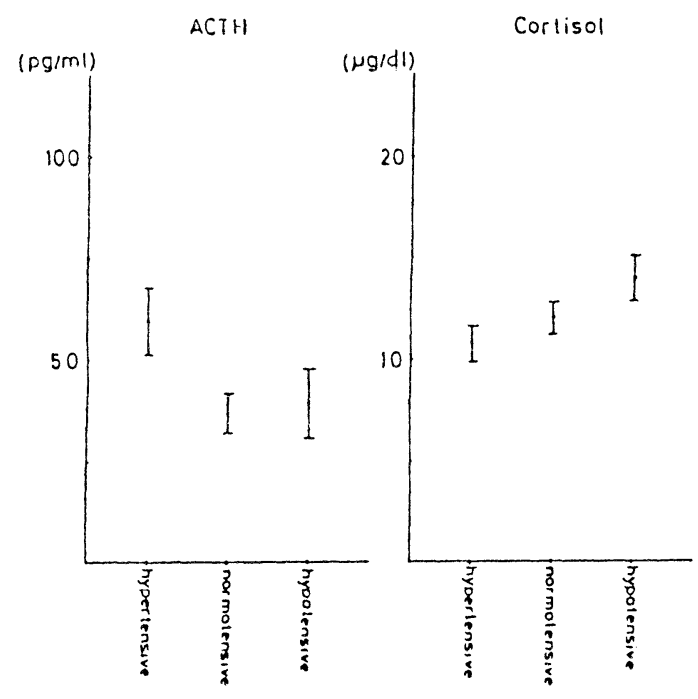

図 1 Plasma ACTH and cortisol level in dialysed patients with chronic renal failure. (Mean \pm S.E.)

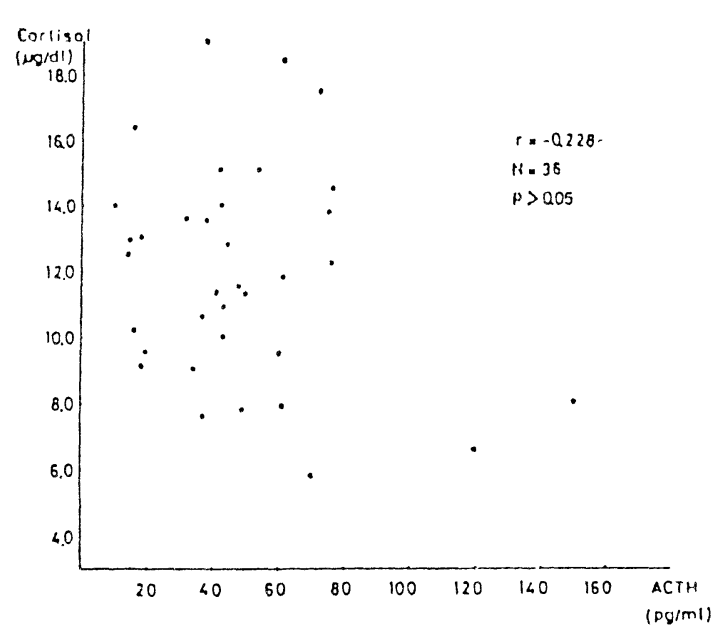

図 2 Correlation between plasma ACTH and cortisol in dialysed patients with chronic renal failure.

の差を認めなかった。

2）血液透析中の慢性腎不全患者の血中 ACTH と cortisol レベルとの関係 (図 2 ).

36 例の対象について血中 ACTH と cortisol レベルの 相関々係を検討したが，弱い負の関係を認めているが有 意な関係ではなかった。

3）血液透析前後の血中 cortisol レベル（図 3 ).

18 例について検討した. 高血圧群は 5 例, 正常血圧群 は 9 例，低血圧群は 4 例である。血液透析前值は $12.5 \pm$ 


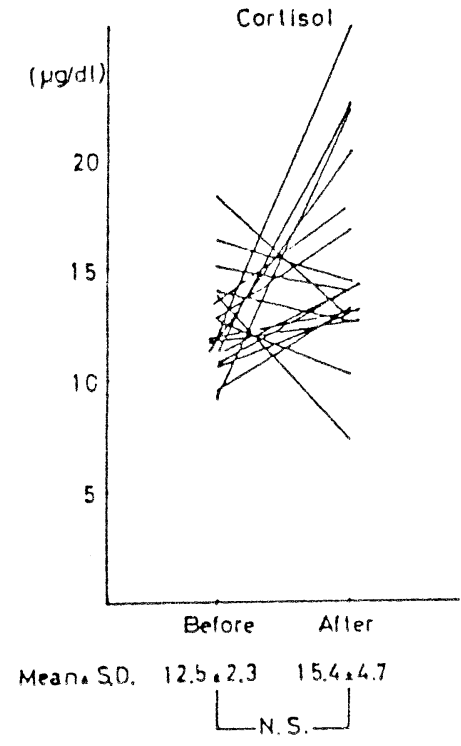

図 3 Plasma cortisol level before and after hemodialysis in patients with chronic renal failure.

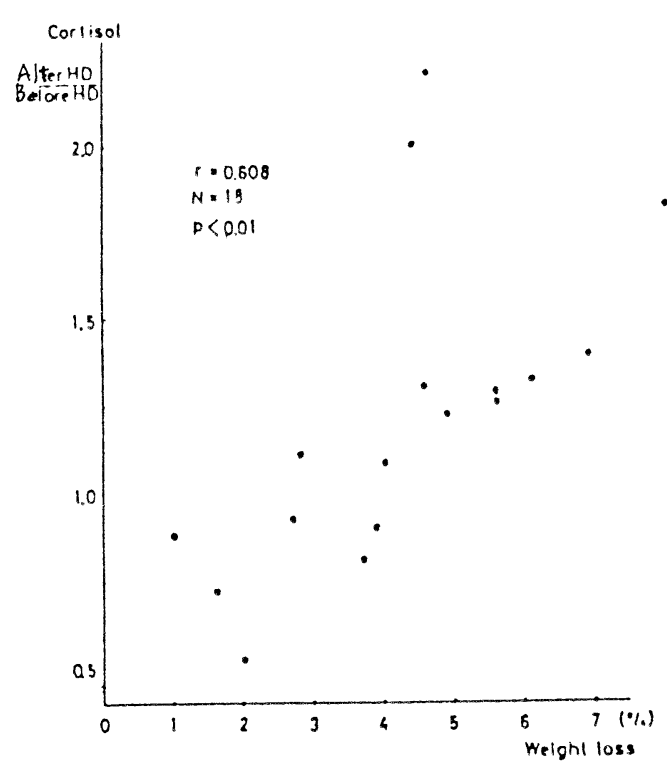

図 4 Correlation between the ratio of plasma cortisol level before and after hemodialysis and weight loss following that.

$2.3 \mu \mathrm{g} / \mathrm{d} l$, 血液透析後值は $15.4 \pm 4.7 \mu \mathrm{g} / \mathrm{d} l$ と上昇傾向 を示したが有意ではなかった。 3 群についてみてみると 高血圧群は血液透析前 $11.3 \pm 2.1 \mu \mathrm{g} / \mathrm{d} l$, 血液透析後 15 . $7 \pm 5.2 \mu \mathrm{g} / \mathrm{d} l$, 正常血圧群では透析前 $11.7 \pm 0.9 \mu \mathrm{g} / \mathrm{d} l$, 透析後 $16.6 \pm 4.7 \mu \mathrm{g} / \mathrm{d} l$, 低血圧群では透析前 $15.9 \pm 1.9$

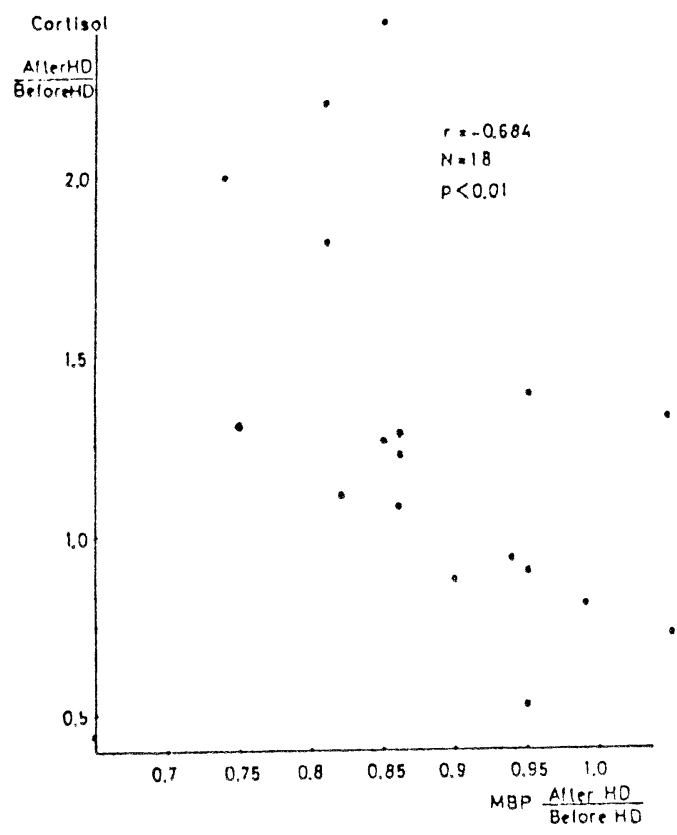

図 5 Correlation between the ratio of plasma cortisol level before and after hemodialysis and that of MBP.

$\mu \mathrm{g} / \mathrm{d} l$, 透析後 $12.2 \pm 3.4 \mu \mathrm{g} / \mathrm{d} l$ であった. 高血圧群及び 正常血圧群では透析後值は前值に比して上昇している が, 低血圧群では透析後值は前值に比して低下していた。 4）血液透析前後の cortisol 比と透析による体重減少率 との関係（図 4 ).

18 症例について検討したところ図 4 に示すごとく 有意な正の相関々係を認めた。つまり透析による水分除 去が多いほど cortisol 值は前值に比して後值が上昇傾向 をみた。

5）血液透析前後の cortisol 比と血液透析前後の中間血 圧の比との関係（図 5 ).

困 5 に示すごとく cortisol透析前後比と中間血圧透 析前後比との間には有意な負の相関々係を認めた。

6）血液透析中の $\mathrm{Na}, \mathrm{K}$, 中間血圧, cortisol の経時的 変化 (図 6 ).

4 症例について検討した。高血圧群 2 例, 正常血圧群 2 例であり, 低血圧群については検討できなかった。 cortisolレベルは 3 時間経過時より上昇傾向を認める が, 中間血圧については cortisolレベルの変化に先立つ て低下傾向を示した. $\mathrm{Na}$ は一定の傾向を示さず, $\mathrm{K}$ は減 少傾向を示した。

7) 腹膜灌流中の ACTH, cortisol の経時的変化 (図 7 ). ヘパリンによる非特異的反応のために ACTH 值が高 值を示すという報告があるのでへパリンを使用しない腹 


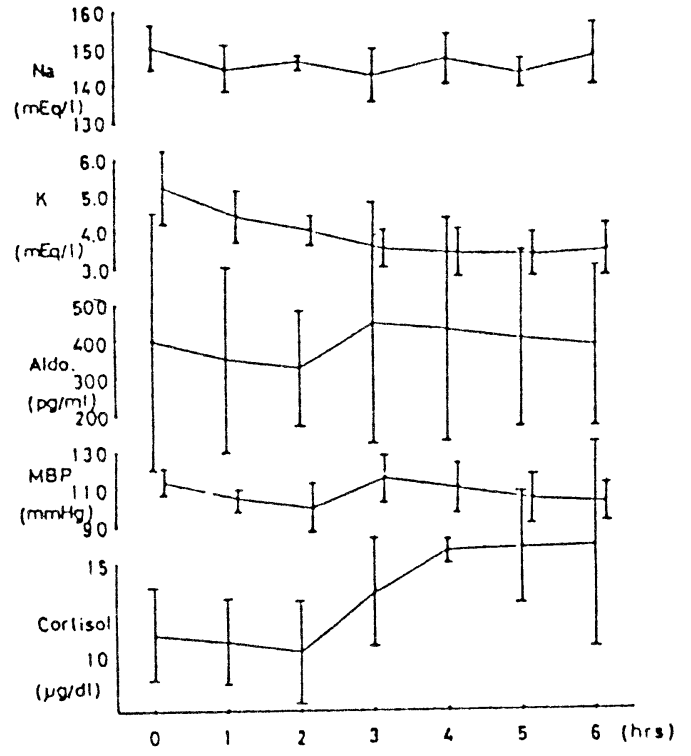

図 6 Changes of $\mathrm{Na}, \mathrm{K}$, aldosterone, MBP and cortisol during hemodialysis.
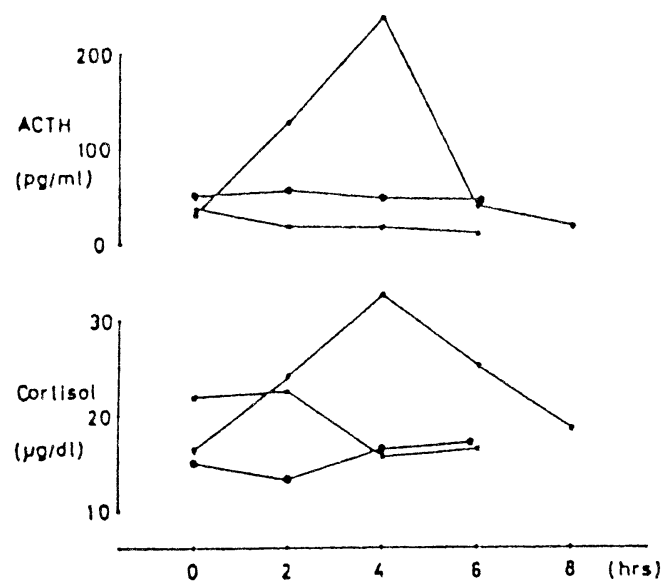

図 7 Changes of ACTH and cortisol level during peritoneal dialysis.

膜灌流患者 3 例について ACTH, cortisol を灌流中 2 時 間ごとに測定した。

3 例の内訳は正常血圧群 2 例, 低血圧群 1 例である. 図 7 に示すごとく低血圧群 1 例についてはACTH, cortisol とも時間の経過とともに下降傾向を示した. 正 常血圧群の 1 例は腹膜灌流開始後 $2 \sim 4$ 時間に腹痛を訴 え, その際 ACTH, cortisol レベルの上昇をみた。他の 1 例は大きな変化を示さなかった。

8）血液透析中の慢性腎不全患者の ACTH, cortisol レ ベルの日内変動（図 8 ）。
ACTH

Corllsol
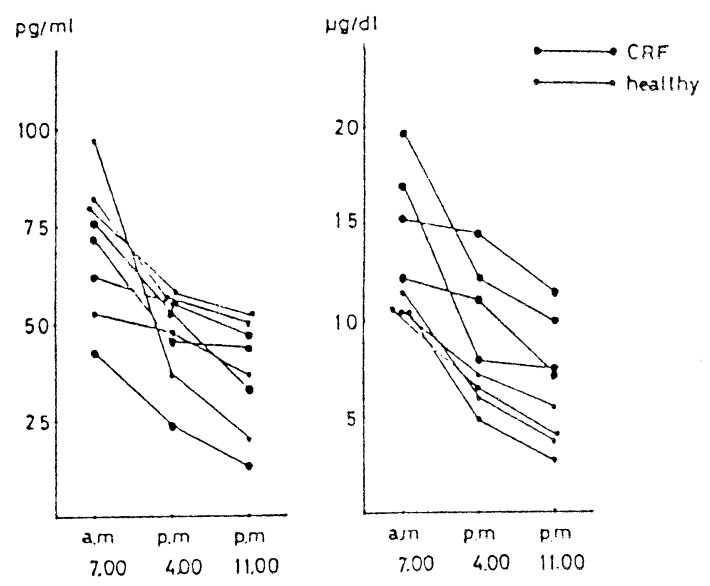

图 8 Diurnal rhythm of plasma ACTH and cortisol level in healthy subjects and in patients with chronic renal failure.

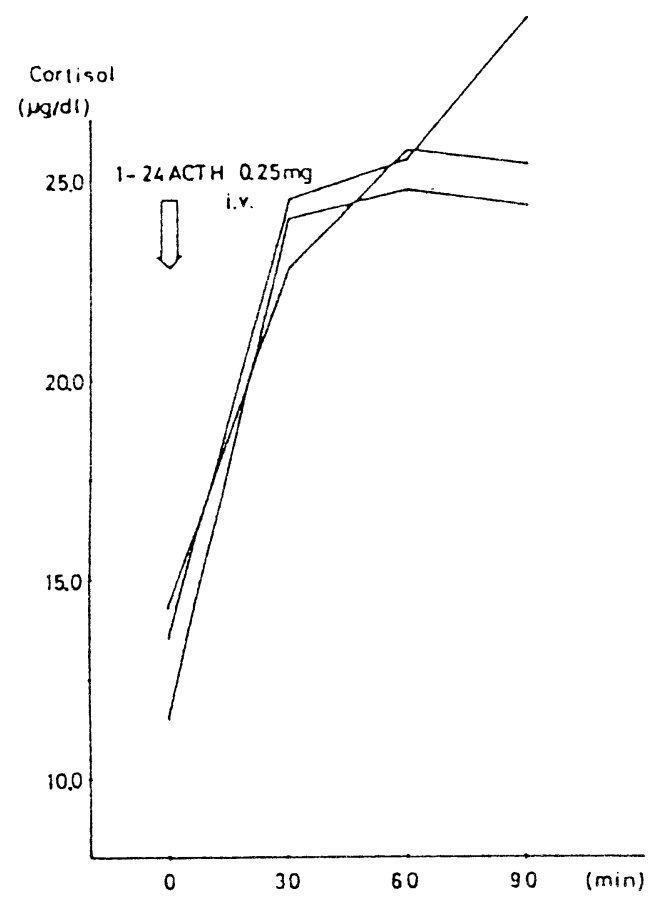

図 9 Rapid ACTH test in dialysed patients with chronic renal failure.

健常人 4 例, 血液透析中の慢性腎不全患者 4 例（高血 圧群 2 例, 正常血圧群 1 例, 低血圧群 1 例) の $\mathrm{ACTH}$, cortisol の日内変動について検討したところ血液透析患 者でも健常人と同様に午前中は高値を示し, 夜間は低值 を示した。日内変動については異常はみられなかった。 
9）血液透析中の慢性腎不全患者の rapid ACTH テス 卜(図 9$)$.

血液透析中の慢性腎不全患者 3 例（高血圧群．正常血 圧群, 低血圧群各 1 例）について透析非施行日の午前 9 時に ${ }^{1-24} \mathrm{ACTH} 0.25 \mathrm{mg}$ を経静脈的に投与して cortisol レベルを 30 分ごとに測定したところ図 9 に示すごとく 正常な反応を示した。

\section{考察}

血液透析中の慢性腎不全患者の透析前值についてみて みると血中 ACTH は正常範囲内にあり, 血漿 cortisol はやや高值を示すがほぼ正常範囲内にあった。血液透析 中の慢性腎不全患者の feedbackのメカニズムをみるた めに ACTH と cortisolレベルについてみたが有意な相 関々係ではないが弱い負の関係みた。血液透析前後及 び経時的に cortisolの変化をみたところ全体として後值 は前值に比して上昇しているが，低血圧群に扔いて後值 は前値に比して低下していたのは興味ある成績であっ た。ささに血液透析による水分除去, 中間血圧の低下が cortisolの分泌に影響をもたらしていることも示され た。血液透析中の ACTH レバルについてはへハリン化 により測定值は非特異的に高値を示すことが知られてお $り^{1}$ ) 予備実験等により抗疑固剂の測定値への影響につい て検討すべきものと思われる。その代りとしてへパリン を使用しない腹膜灌流中の慢性腎不全患者において検討 したところ ACTH, cortisol レベルはほぼ平行した変化 を示した。健常人, 血液透析患者で ACTH, cortisol レ ベルの日内変動についてみたが同様のパ夕ーンを示し た。さらに下垂体一副腎皮質系機能について検討するた めに rapid ACTH テストを実施したが異常はみられな かった。

血液透析中の慢性腎不全患者の cortisol レベルについ て検討した報告は比較的多くみられる. Smith ${ }^{2)}$ は 9 例の 血液透析中の患者において検討したところ透析前のレベ ルは比較的高値を示し透析開始後 4 時間， 6 時間のレべ ルはさらに上昇していたことを報告している. Tsuchida $ら^{3)}$ も同様の成績を報告しており，透析終了後の検討で は 12〜24 時間後透析前値に回復したと述べている.しか し川村ら"蛙中 cortisolレベルは正常下限であったこ とを示した。さらに奈良ら゙ は cortisol 基礎值はほぼ正 常範囲内に要るが幅広い分布を示したことを報告してい る. 著者らの成績も Smith $^{2)} や$ Tsuchida ら ${ }^{31}$ の成績とほ ぼ一致しており，血液透析中の経時的変化及び透析後の 成績でも大きな相違はみられなかった。このような比較 的高值を示した cortisol 基礎值及び血液透析中の変化の 原因としてまず最初に透析に伴うストレスが考えられ る. 透析による水分除去量や中間血圧の透析前後の変化
が cortisol 透析前後比との間に相関関係をみたことは透 析による水分除去や血圧低下が著しければ cortisol の変 動が大きいことを示している。こ扎は除水に伴う血圧低 下によりストレスとして下垂体・副腎皮質系が反応し cortisolの分泌が生じたものと思われる.

cortisolの代謝については大部分肝，一部分は腎で代 謝され尿中に排泄される ${ }^{6 / 7)}$. しかしながら腎機能が障害 されている場合血中濃度や尿中排泄に変化がおこること が考えられる.

舟生 ${ }^{8)}$ は腎機能障害者に ACTH-Z 負荷試験，cortisol 注入試験を行ったところ尿中総 17-OHCS 值は腎の クレアチニン・クリアランスの低下にきわめて良く相関 し低值を示したこと及び透析患者の血中遊離型 11OHCS 值注ほ正常範囲内であったが日内変動に異常 がみられたことを報告している. Sederberg Olsenら"は 8 例の腎機能障害の患者に cortisol を経静脈的に投与し て検討したところ尿中の遊離型の cortisol は GFR の低 下とともに減少したが血中の遊離型の cortisolの増加は GFRには相関しなかったこと及び尿中の cortisolの測 定は腎機能障害の患者ではほとんど価值がないことを報 告している。 Englertら ${ }^{10)}$ は慢性腎疾患患者に扔いて AM8:00の血中 17 - OHCS (free 17- hydroxy corticosteroid）レベルは正常であり結合型のレベルは上昇し ており内因性クレアチニンクリアランスと逆相関したこ と及び cortisolの注入によって遊離型のレベルは指数的 に減少したが正常人より遅延しており, 結合型のレベル は正常人よりはるかに上昇した。また 17-OHCSの尿中 排泄も低下しており GFRの低下と相関したことを報告 している. 総 cortisol レベルは著者らの成績では正常範 囲及びやや高值にあることから cortisolの血中の半減期 について文献的に考察を加えてみた。

Baconら"はグループAとして腎疾患をもち血清クレ アチニンが $7 \mathrm{mg} / \mathrm{d} l$ 以上で血液透析開始前の症例, 血清 クレアチニンが $7 \mathrm{mg} / \mathrm{d} l$ 以下で将来血液透析を実施す る予定の症例をグループ B, そして健常人の 3 群に打い て血清 cortisol濃度及び半減期についてみたところ cortisol 濃度は 3 群とも変わらなかったが血中半減期は グループAにて著明に延長していたことを報告してい る。このように血液透析中の患者においては cortisolの 半隇期が健常人に比して著明に延長しているが血中レベ ルが正常範囲内にあることは cortisolの生成と崩壊が代 償的に適合しているものと思われる。

さらに透析中の cortisol レベルが上昇する原因として 血中より非結合の遊離型 cortisol が透析される結果, $\mathrm{ACTH} 介$ オる feedback 機構により大量の cortisol が分泌されるものと思われる。 
著者らの成績でも ACTH と cortisol は有意ではない が弱い負の関係をみたことから feedback 機構は血液透 析中の慢性腎不全患者でも正常に働いているものと判断 される。

血圧の状態によって血液透析患者を分類し透析中の cortisolの経時的変化をみた報告もあり, 奈良ら ${ }^{5)}$ は血液 透析後の血圧によって低血圧群と非低血圧群に分類して 検討したところ非低血圧群は低血圧群に比して cortisol 值は透析後の増加が低い傾向にあったこと及び透析前の cortisol 值については 2 群の間に差はみられなかったこ とを報告している。橘内ら ${ }^{12)}$ は血液透析前の血圧を分類 して透析中の cortisol の変化について検討したところ正 常血圧群では著変なく低血圧群で上昇し, 高血圧群では 低下したという報告がみられ著者らの成績とは異った。 これについては著者らは透析前に低血圧を呈した群につ いては透析時体外循環血量及び限外濾過圧を比較的おと して水分除去量を低下させショックの発生の防止をはか ったことがストレスの発生を防止し cortisol の分泌を㧍 さえることになったことが原因と考えている。

血液透析中の慢性腎不全患者に扔ける ACTHレベル について検討した報告は少ない. Gilkesら ${ }^{13)}$ はSH 及 びACTH を測定したデーターを報告しているが血中 ACTH レベルは正常かやや上昇していたことを報告し ている.同様に Bertagna ら ${ }^{14)}$ の報告もみられる. 本邦で は奈良ら ${ }^{5)}$ は透析前後の ACTH は不変で正常であった ことを報告している。橘内ら ${ }^{12)}$ 涊患者の透析前の血圧に よって患者を分類し ACTH レベルを検討しているがど の群も透析前後のレベルは正常であり透析によっても変 化は生じなかったと報告している。このような報告は著 者らの成績とも一致して抢り，さらに腹膜灌流中の患者 にて灌流中 ACTH, cortisol レベルが平行した動きを示 したことも橘内ら ${ }^{12)}$ の血液透析中の患者の ACTH, cortisolの経時的変化についての報告と一致した。

ACTHの代謝について腎不全患者において検討した報 告はほとんどないが川越ら ${ }^{15}$ の radioimmunoassay に よって ACTHの metabolic clearance rate を検討した 成績では正常人は $462 \pm 30(\mathrm{SE}) \quad 1 /$ day に比して腎不全

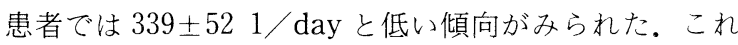
も慢性腎不全患者の ACTH の生成と崩壊が代償的に適 合しているものと考えられた。

血中 ACTH, cortisol の日内変動については著者らの 成績ではほぼ健常人と同様のパターンをとることが示さ

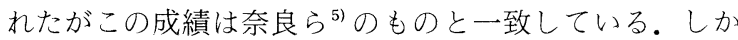
し川村ら ${ }^{4)}$ (慢性血液透析患者の cortisol の日内変動は ゆるやかで朝夕の変化に乏しいと述べている。この原因 としては透析の影響により昼間の cortisol レベルの上昇
によって夕方にはまだ朝のレベルで夜間に若干低下し て, 翌日の非透析日には変化の少ない日内リズムが繰返 されるのだろうと考えられている。

血液透析中の慢性腎不全患者の視床下部一下垂体一副 腎皮質系の機能は rapid ACTH テストにより正常に反 応したことから特に異常はないと考えられた。著者らは dexamethasone 抑制試験を行っていないが Barbour $ら^{(6)}$ ，橘内ら ${ }^{12)}$ の成績でも ACTH テスト， dexamethasone 抑制試験で正常の反応を示したことが報告されて いる.

以上の成績より血液透析中の慢性腎不全患者の下垂体 一副腎皮質機能汁大きな異常は認められないものと思わ れた。ささらに透析中低血圧を呈する患者では下垂体一副 腎皮質が強く反応し， cortisolが分泌されることが示さ れたが，血液透析前の低血圧の成因として下垂体一副腎 皮質が関与している可能性は少ないものと思わ机た。

\section{結論}

血液透析中の慢性腎不全患者の低血圧の成因を解明す るために下垂体一副㹂皮質機能について検討したところ 次のような成績をえた。

（1）血液透析中の慢性腎不全患者の血中 ACTH レ心゙ ルは正常範囲内にあり, 血漿 cortisol レベルも正常範囲 よりやや高值を示した。低血圧群，正常血圧群，高血圧 群の 3 群の間には ACTH, cortisol レベルとも有意の差 を認めなかった。

（2）血液透析中の慢性腎不全患者の ACTH と cortisol レベルの間には有意の関係ではないが弱い負の関 係をみた。

（3）血液透析前後の血中 cortisol レベルは全体として 透析後は透析前に比して高值を示したが低血圧群では後 值は前値に比して低下していた。

（4）血液透析前後の cortisol 比と透析による体重減少 率及び血液透析前後の中間血圧の比については有意な関 係をみた。すなわち透析による水分除去量，中間血圧の 低下が大きいほど cortisol 值は上昇をみた。

（5）腹膜灌流中の慢性腎不全患者の灌流中の経時的変 化では ACTH, cortisolレベルは平行した関係を示し た.

（6）血液透析中の慢性腎不全患者の ACTH，cortisol レベルの日内変動は健常人と同一のパターンを示した。

（7）血液透析中の慢性腎不全患者の rapid ACTH テ ストは正常であった。

以上の成績より血液透析中の慢性腎不全患者の下垂体 一副㹂皮質機能はほぼ正常であり，血液透析前の低血圧 の成因として下垂体一副腎皮質が関与している可能性は 少ないものと思われた。 
(本論文の要旨は第 20 回日本腎臟学会総会において発 表した).

\section{文献}

1) 稲田満夫, 西川光重, 大石まり子, 蔵田駿一郎 : ACTH Radioimmunoassay Kit (CEA - IRE SORIN) の基礎的検討とその臨床応用について，木 ルモンと臨床 26：807-811，1978.

2) Smith, M. J. : Adrenal stress during hemodialysis. Proc. Eur. Dial. Trans. Ass. 3 : 300-301, 1965.

3) Tsuchida, S., Sugawara, H. and Fukuchi, S: Plasma cortisol level during hemodialysis with Kolff's artificial kidney. Tohoku J. Exp. Med. $100: 23-29,1970$.

4) 川村寿一, 岡部達一郎, 山下青世, 沢西謙二, 加藤 篤二, 本田弘, 吉見輝也, 岩井一義: 慢性血液透析 患者の副腎皮質機能，日腎誌 $14 ： 220 ， 1972$.

5）奈良芳則, 田尻正記, 高橋幸雄, 今井久, 平沢由平, 山田幸男, 浜斉: 長期透析患者の下垂体-副腎皮質機 能について, 日腎誌 $19: 512,1977$.

6) Schenider, J. J. and Horstmann, P. M. : Effects of incubating compound $\mathrm{E}$ and related steroids with various surviving rat tissues. J. Biol. Chem. 196 : 629-638, 1952.

7) Ganis, F. M.- Axelrod, L. R. and Miller, L. L. : The metabolism hydrocortisone by kidney tissue in vitro. J. Biol. Chem. 218: 841-848, 1956.

8）舟生富寿, 工藤茂宣，大野和美，二川原和男，人見 浩，鈴木唯司，三国恒靖，寺山百合子，青木敬治， 平山順朗，小野寺孝夫，菅原茂：慢性腎機能障害患 者に抢ける副腎皮質ホルモンの代謝，日腎誌 17 ： 823-835, 1975.

9) Sederberg-Olsen, P., Binder, C. and Kehlet, H. : Urinary excretion of free cortisol in impaired renal function. Acta endocrinol. (Kbh) $78: 86-90$, 1975.

10) Englert, E., Jr., Brown, H., Willardson D. G., Wallach, S. and Simons, E. L. : Metabolism of free and conjugated 17-hydroxy corticosteroids in subjects with uremia. J. Clin, Endocrinol. Metab. $18: 36-48,1958$.

11) Bacon, G. E.- Kenny, F. M., Murdaugh, H. V. and Richards, C. : Prolonged serum half-life of cortisol in renal failure. Johns Hopkins Med. J. 132 : 127-131, 1973.

12）橘内芳一, 春山和美, 高橋重雄, 小川!さつき, 福地 総逸：血液透析前後における血中 ACTH 抢上び血 中コーチゾール含量の変動, 人工透析研究会会誌 $11: 377-378,1978$.

3) Gilkes, J. J. J., Eady, R. A., Rees, L. H., Munro, D. D. and Moorhead, J. F. : Plasma immunoreactive melanotrophic hormones in patients on maintenance haemodialysis. Br. Med. J. 1: 656-657, 1975.

14) Bertagna, X., Donnadieu, M., Idatte, J. and Girard, F.: Dynamics and characterization of plasma immunoreactive $\beta$-melanocyte stimulating hormone in hemodialysis patients: Its relationship to ACTH. J. Clin. Endocrinol. Metab. $45: 1179-1186,1977$.

15）川越光博, 斉藤栄造, 阿部好文, 市川陽一, 本間光 夫, 清水節, 大山建司, 野村正紀, 有川一美, 吉田 幸一郎, 岡本二郎：ACTH代謝動態に関する研究, 第 2 報, 甲状腺機能異常, 肝不全, 腎不全における ACTH の MCR，日内分泌誌 $52 ： 356 ， 1976$.

16) Barbour, G. L. and Sevier, B. R. : Adrenal responsiveness in chronic hemodialysis. N. Engl. J. Med. $290: 1258,1974$. 